\title{
CREDIT AND MONEY IN SCHUMPETER'S THEORY
}

di

\author{
Marcello Messori* \\ Department of 'Economia e Istituzioni' \\ University of Rome (Italy)
}

Together with Wicksell and other German speaking authors, Schumpeter re-defined the foundations of monetary theory replacing the traditional view of money as a "veil", which facilitates exchanges, with the concept of money as capital, which acts as an essential premise for the starting of new production processes. However, these results were not enough to give credit to Schumpeter as monetary theorist. The present paper aims to show that this scanty renown of Schumpeter's monetary theory is due to his attempt to reach a close integration between the monetary and the 'real' aspects of the economic system. This attempt implies, in fact, that Schumpeter does not examine the traditional monetary problems but deals with those money functions which are an essential part of the cyclical evolution of the economic system. Such functions, in their turn, found the so-called 'credit theory of money', as opposed to the 'monetary theory of credit'. The 'credit theory of money' represents the main subject of this paper.

(*) Marcello Messori

Dipartimento di Economia e Istituzioni

\footnotetext{
* I wish to thank the participants to a Conference (Università di Bergamo) and Seminars (Université de Paris X, Università 'Tor Vergata' di Roma, and Università di Torino), where I presented this paper; I am particularly indebted with an anonimous referee who made useful comments on a first draft prepared for the Conference at Bergamo. The financial support by Italian MURST is gratefully acknowledged.
} 
Università di Roma 'Tor Vergata'

Via Columbia, 200133 Roma (Italy)

e-mail: messori@uniroma2.it 


\section{CREDIT AND MONEY IN SCHUMPETER'S THEORY \\ di \\ Marcello Messori}

\section{Introduction}

Together with Wicksell (1898) and other German speaking authors (for example, A. Hahn (1920)), Schumpeter re-defined the foundations of monetary theory replacing the traditional view of money as a "veil", which facilitates exchanges, with the concept of money as capital, which acts as an essential premise for the starting of new production processes 1 . This means that, analogously to Keynes ((1930) and (1936)), Schumpeter criticized the quantity theory of money but, unlike Keynes (1936), he based his criticism on the function of money as a means of payment rather than as a store of value. Thus, putting into other words a famous statement made by Robertson, ((1940), p.12), whilst Keynes (1936) underlined the willingness of the individual agents to hold money as a stock, Schumpeter insisted on their wish to take possession of money in order to use it as a flow. Moreover, Schumpeter proved that the flows of money matter for the "real" variables, especially if obtained before the sale of produced goods and services (see also: Robertson (1926)).

However, these results were not enough to give credit to Schumpeter as a monetary theorist. According to many historians of the economic analysis, the Schumpeterian framework of cyclical development is centered on the process of innovation and

\footnotetext{
1 It should be noted that, at least according to Klausinger (1990), Schumpeter ((1908) and (1912)) himself can claim the autorship for the expression "veil of money". The differences between Schumpeter's and Wicksell's monetary theories will be dealt with at a later stage (see sec.4; cf. also Messori (1996).
} 
on the role of the entrepreneur rather than on the availability of credit and on the role of banks; therefore, this framework should be confined within the boundaries of the theory of economic development and of the industrial economics. On the other hand, the writings in which Schumpeter dealt predominantly with monetary issues are few compared to his whole work 2 .

The narrow number and the scanty renown of Schumpeter's contributions on money can be attributed to the main characteristics of his monetary theory. By criticizing the traditional form of the quantity theory of money and by stating that money as capital acts as an essential premise for the starting of new production processes at the basis of the cyclical development, Schumpeter aims to reach a close integration between the monetary and the 'real' aspects of the economic system. Such aim is already clear in Schumpeter (1908), where the analysis of the economic development has not yet been elaborated ${ }^{3}$. By inferring the existence and the role of money from the theories of exchange and price, Schumpeter affirms that the theory of money

\footnotetext{
2 It should be noted that, taking also into consideration the chapters included in volumes, Schumpeter's monetary writings number slightly over a dozen. Moreover it should be noted that, in grouping the 1916 works on Schumpeter into eight categories, Augello ((1990), pp. 21-4) highlights that the works dedicated to 'money' are largely lesser in number than those concerning 'development' and 'politics'. However, the 'money' category includes over 170 references; and its rate of growth is faster than the average in the last decades. Graziani (for instance: (1977), (1978), and (1982)) mainly contributed to this growing interest in Schumpeter's monetary theory.

3 Schumpeter (1908) points out the limits of a framework confined to the stationary state or to the "growth", and introduces some of the crucial concepts for the analysis of the cyclical development. The first framework which includes the cyclical development, is however offered by Schumpeter (1910).
} 
"constitutes an integral part of the system of pure economics, in the sense that it cannot be separated from the remaining parts of this system" ((1908), p. 279; cf. also Reclam (1984), p.9). This statement is confirmed in various passages of Schumpeter's later works which focus on cyclical development. For example, Schumpeter states ((1939), p. 548; cf. also: (1970), pp. 1-2):

economic action cannot, at least in capitalist society, be explained without taking account of money, and practically all economic propositions are relative to the modus operandi of a given monetary system;

but, immediately after, he adds:

that economic analysis cannot [...] abstract from money is a truth which is useful only if supplemented by the other truth that monetary processes never carry their explanation in themselves and cannot be analized in monetary terms alone 4

The passages just quoted clarify why Schumpeter's most important writings do not isolate the analysis of the monetary aspects with respect to that of the 'real' aspects. To a certain extent, this also applies to Schumpeter's Theory on Money and Banking 5 and to his few articles which specifically deal with

\footnotetext{
4 Similar thoughts can be found in Schumpeter ((1948); and (1954), p. 292 n.). Furthermore, Schumpeter notes that "stationary capitalism is a contradiction in terms" (Schumpeter (1943), p. 174; cf. also (1936), p. 155; (1946a), p. 193) and has to include, amongst is fundamental features, "the creation of means of payments [...] by private banks" ((1943), p. 170; cf. also: (1928), p. 48).

5 For reasons clarified in Messori (1997), from now on such title will indicate the twelve chapters of Schumpeter's treatise on money published posthumous as Das Wesen des Geldes (see Schumpeter (1970)), and the three additional
} 
monetary matters (e.g. Schumpeter (1917-18)). In such works the monetary part assumes a predominant weight and it is dedicated to the investigation of those concepts which, even if playing an important role for the integration between the monetary and the 'real' aspects of the cyclical development, do not find a suitable analytical treatment in Schumpeter's contributions of a more general content. Therefore, Schumpeter's main monetary writings do not examine the traditional monetary problems but deal with the difficult task of giving analytical capacity to those money functions which are an essential part of the cyclical evolution of the economic system.

In order to accomplish such a task, one needs to elaborate a monetary theory which fits with the analysis of the cyclical development. Various commentators maintain that Schumpeter does not go further than outlining such a 'dynamic' theory of money and that, as a consequence, he is not able to specify the relations between money and credit in the various phases of the economic cycle. The aim of the present paper is to challenge such a negative judgement, and to prove that: (i) Schumpeter's analysis of credit and money functions, within the cyclical development, leads to an elaborated monetary theory; (ii) even if such theory leaves various problems unsolved, one of its basic features consists exactly in specifying the links between the functions carried out - respectively - by money and by credit.

In what follows both the meaning of 'dynamic' theory of money and the links between money and credit will be defined more precisely by recurring to a distinction made by Schumpeter himself (in particular, 1954), between the "credit theory of money" and the "monetary theory of credit" (section 2). Besides presupposing a

chapters of this treatise published for the first time in an Italian edition (see Schumpeter (1996), Part I). 
re-definition of the concept of money and a criticism of the traditional monetary framework, Schumpeter's formulation of a credit theory of money is fundamental for stressing that the bank credit lent to entrepreneurs during the economic development acts as (money-)capital (section 3). Schumpeter's examination of the role of money capital highlights the macro and microeconomic sequence characterizing the cyclical evolution (sections 4 and 5). This examination, however, cannot deal with all the problems raised by Schumpeter's monetary theory. In the Conclusions the main unsolved problems will be underlined, and their possible developments will be touched upon.

\section{The credit theory of money}

The research program followed by Schumpeter is well summarized in his "Preface" to the Japanese edition of the Theorie der wirtschaftlichen Entwicklung (Schumpeter (1912)) through his highly regarded although critical reference to the Walrasian general equilibrium model (Schumpeter (1937), pp.15960; also (1954), pp.242 and 998-1026). According to Schumpeter, Walras' apparatus represents a milestone of economic theory but it is "static in character", that is, it is restricted to determining the conditions for the existence and stability of the equilibrium, and apply only to a stationary process, that is, to a process without discontinuous endogenous changes and with passive adaptations to exogenous changes 6 . Furthermore, in Walras' conception, the

\footnotetext{
6 Although warning not to confuse the "static conditions" and the "stationary conditions" (see also Schumpeter (1927b); Marget (1938), p.41; Marget (1942), pp.112-3 and 361), Schumpeter (1937) turns the latter into a particular case of the former which are, in turn, assimilated to the situations of equilibrium. The result is, as showed in the two German editions of the Theorie (cf. Schumpeter (1912), pp.76-80), that Schumpeter ends up by contrasting the 'staticstationary-equilibrium' concepts to the 'dynamic-development-disequilibrium'
} 
analysis of the stationary processes exhausts the field of the economic theory. Instead, analogously to Marx, Schumpeter maintains that there is a "source of energy within the economic system" able to disrupt "any equilibrium that may be attained". From it, Schumpeter ((1937), p.160) derives that:

there must be a purely economic theory of economic change which does not merely rely on external factors propelling the economic system from an equilibrium to another. It is such a theory that I have tried to build [...].

This means that the stationary state must be treated as a specific case, or, better saying, as the starting point and as the (temporary) point of arrival of the process of cyclical development ${ }^{7}$.

ones. However, when presenting the English edition of the Theorie (cf Schumpeter (1934), p. xi; cf. also the added footnote at p.64), Schumpeter acknowledges the ambiguity of this use of the terms 'statics' and 'dynamics'. With the exception of the convenient expression of "'dynamic' theory of money", in this paper I will avoid assimilating statics to the circular flow or to the stationary state (cf. also below, n. 7) and dynamics to development.

7 In this paper, I am not concerned with the problem of whether Schumpeter's stationary state represents either an 'ideal' reference point or a part of the economic process. It is sufficient to remember that such a stationary state: (i) can easily be extended to the circular flow with growth or exogenous changes (cf. Schumpeter (1912), ch..I); (ii) it must act as a premise of the economic development both for avoiding misinterpretation between what explains and what needs to be explained (cf. Schumpeter (1910), p. 277; (1912), p. 89; engl. trans., p.58), and for founding analytically the entrepreneurial choices (cf. Schumpeter (1912), p. 347; engl. trans., pp. 235-36; (1939), pp. 135-6); (iii) it characterizes the new equilibrium, into whose "neighborhoods" the phase of recessive adaptation tends to flow in the two-phase cycle (cf. Schumpeter (1939), pp.70-1); (iv) it favours but does not guarantee the reproduction of the economic development since the mechanical conception "according to which there would be booms because there are depressions, and depressions because 
Schumpeter raises analogous remarks concerning Walras' monetary theory. After having affirmed that this theory integrates with the 'real' aspects of the general equilibrium system and thus marks an important progress, he adds that this same theory leads to a static conception of money since it applies to a stationary state and cannot be extended to the economic development (Schumpeter (1954), p.1082; cf. also (1917-18), p.33; engl. trans., p.150). Moreover, Schumpeter ((1954), pp. 1020-26) maintains that this limit is due to analytical reasons. Walras $\left(1900^{4}\right)$ manages to integrate monetary and 'real' aspects of his economic system through the assimilation of money to one of the funds (or stores of goods) which offer a service as stock and which are exchanged in the "circulating capital" market ${ }^{8}$. The price of money as store is determined by the demand of its service ("encaisse désirée"), and by the amount of its stock. The influence exerted by this price directly on the prices of capital goods and other stores, and indirectly on the remaining prices and on all the quantities, implies however the dependence of the encaisse désirée themselves on the price of money service. Hence the encaisse désirée too should be an endogenous variable determined simultaneously to other quantities. However, apart from making the proof of the existence and stability of the economic equilibrium more complicated ${ }^{9}$, this would prevent Walras' model from determining

there are booms" is refused (cf. Schumpeter (1927b), p. 29; cf. also: (1912), p. 336; engl. trans., p. 225; Stolper (1982), pp. 30 and 42).

8 In order to distinguish the stores of money from the stores of goods, Walras affirms that the exchanges of money services are realized in a specific market called marché du capital. In Walras' terminology, the marché des capitaux refers, instead, to the market in which capital goods are exchanged.

9 According to Schumpeter ((1954), pp. 1024-5), Walras chose to neglect the effects that the value of the overall transactions exert on the encaisse désirée in 
those additional variables which are necessary for the analysis of money as a flow. Walras (1898) singles out some mechanisms of banks creation of means of payments, but he considers these mechanisms as being a source of instability and abuse and he expunges them from his theoretic al apparatus (Walras $\left(1900^{4}\right)$ ).

At this stage it is not possible to enter upon Schumpeter's interpretation, according to which Walras' definition of encaisse désirée brings the demand for money back to "the wish to hold stocks of money" and, therefore, anticipates the essential aspects of Hicks' (1935) and Keynes' ((1936), chs.15 and 17) portfolio theories. What is certain is that Schumpeter has a critical attitude towards such conception of money:

A man may, for example, hold a supernormal amount of cash, not because this is any good to him, but simply because his and other people's actions happen to produce that result, which in itself is not one of the objects he wishes to attain by those actions [...]. All explanations which start with the famous adage: 'if people choose to hold...', are ipso facto condemned" (Schumpeter (1939), pp. 547-48; cf. also (1970), p.301).

This clarifies Schumpeter's attempt to build a 'dynamic' theory of money as a flow 10 : outside the stationary states, the demand to

order to avoid such complications. However, Schumpeter maintains that this simplification cannot be accepted because, as Walras himself $\left(1900^{4}\right)$ recognizes, it leads to the separation between the money equation and the system of equations of the 'real' part of the economic system with the consequent relapse into the conception of the money as a 'veil'.

10 By criticizing Walras' theory of money and its "new lease of life" (cf. for the last expression: Schumpeter (1939), p. 547), Schumpeter is also intent on criticizing Keynes' definition (1936) (see also: Schumpeter (1936) and (1946b)). 
hold money is due not to individual and voluntary (equilibrium) decisions but to unexpected (disequilibrium) outcomes of individual plans or to time lags between individual receipts and disbursements. It is worth noting that Hicks too (cf. (1967), pp. 14-6) maintains that the store of money held for transactions is not the result of a "voluntary demand", based on "individual decisions" or on the aggregation of individual choices, but the temporary result of the actual streams of payments or the effect of an unexpected amount of transactions. However, Hicks' criticism does not go as far as involving the store of money held for speculative or - especially - for precautionary motives (see Hicks 1967, lecture III). Conversely, as the above passage points out, Schumpeter's criticism to the demand to hold money covers the concept of stock of money as such ${ }^{11}$.

However, in order to go over Walras' definition of money, Schumpeter has to criticize not only the demand for money as a stock, but also the traditional view of money as a "veil" which does not affect the 'real' working of the economic system. This implies that Schumpeter has to prove the influence of money on the 'real' variables by only referring to the monetary flows. The essential role played by the monetary flows for the accomplishment of Schumpeter's cyclical changes is based on the introduction into the economic system of the new means of payments created by banks. This 'creation' leads to the so called "credit theory of money". As will be shortly pointed out, Schumpeter's credit theory

\footnotetext{
11 In various passages (e.g.: (1970), pp. 301-2) Schumpeter recognizes that the stores of money held by the individual agents (firms, households) can be the result of intentional actions. He also adds that the operating of bank credit increases the intentional character of these stores. However, in such passages, Schumpeter also stresses that these aspects are irrelevant for the theoretical representation of the economic working. Furthermore, he tends to exclude money stocks from his definition of money.
} 
of money has the merit of showing how the importance of bank credit lies in its function of money capital (e.g.: Schumpeter (1970), p. 82). However, such a theory pushes too far the idea that money - in the strict sense of the word - can be assimilated to credit, and consequently that the availability of credit flows empties the (precautionary) function traditionally performed by money stocks 12 .

The formulation of a credit theory of money is present in Schumpeter's work as far back as 1912. However, it finds completion in the History of economic analysis thanks to a comparison with the "monetary theory of credit". According to Schumpeter, the supporters of this latter doctrine offer a definition of 'means of payment' which is so extensive as to include the bank deposits and the bills of exchange besides the various types of money and currency. However only money, in the strict sense of the word, is the "good" acting as unit of account, means of payment and store of value. The credit means of payment can temporarily (and partially) replace money; nevertheless, money stricto sensu remains at the analytical foundations of credit since the settlement of each payment and of each loan has to occur in money. The creation of means of payment by banks is thus mechanically constrained by their amount of reserves in money stricto sensu. According to Schumpeter, it follows that the monetary theory of credit prevents the examination of the working of the credit market, and can be assimilated to a modern form of that traditional theory which affirms that the only function of the

12 Hicks' most recent monetary analysis ((1982), part IV; (1989), part II) has sketched a way for integrating bank credit and the demand to hold liquidity for precautionary motives. A first attempt to develop Hicks' suggestions is offered in: Messori-Tamborini (1995). Shortly, it will be clear to what extent this differs from Schumpeter's credit theory of money. 
means of payment and of money stricto sensu is to 'facilitate' the exchanges between goods and services without affecting their quantity and their relative prices.

Schumpeter maintains that, in order to escape from such a result, it is necessary to take into account three monetary aspects of the capitalist economic development: (i) the realization of new productions which break off the stationary equilibrium and begin the development process, requires the introduction of additional means of payment into the system relative to the quantity of money circulating in the circular flow (cf. Schumpeter (1912), p. 108; engl. trans., pp. 72-3; (1939), pp. 110-1; (1970), p.297); (ii) such additional means of payment are made available by the bank supply of credit and, therefore, represent newly created 'claims' on money which carry out its same functions ${ }^{13}$; (iii) unlike money circulating in the stationary state, the availability of 'claims' on money does not vouch for a previous personal or material contribution to the economic activities but instead allows the participation to the "national dividend" before having brought any service or good ${ }^{14}$. Points (i)-(iii) found Schumpeter's credit theory

13 Cf. Schumpeter (1912), pp. 140 and 142; engl. trans., pp. 95 and 97; (191718), pp.56-7; engl. trans., pp. 167-68; (1927a), p.85 n., (1970), p. 233 . See also the first part of the unpublished chapter XIV of Theory of money and banking, available in Italian (cf. Schumpeter (1996)). It should be noted that Schumpeter ((1939), pp. 578-81) lists eleven possible sources of financing, and some of these sources do not increase the amount of means of payment (cf. also Earley (1983), pp. 9-15). However, as Schumpeter himself underlines ((1939), p. 578), this list does not refer to "the origin of the cyclical process" but goes "away from it". Following Schumpeter's model of "first approximation" (two-phase cycle), I, therefore, restrict the analysis to bank credit (see also Schumpeter (1970), pp. 149 and 230).

${ }^{14}$ Cf. Scumpeter (1912), pp. 109-10; engl. trans., pp. 73-4; 1917-18, p. 38; engl. trans., p. 154; 1939, p.123; 1970, pp. 297- 8. See also Graziani (1978), p. 463. 
of money. Point (i) clarifies that the additional 'claims' on money are required by the agents who carry out the new productions (that is, the entrepreneurs). Point (ii) highlights that banks usually create new means of payments, and both money and the 'claims' on money can act as capital since they constitute a 'voucher' on the productive services and not only on the final goods. Point (iii) stresses that the credit means of payment are not analytically founded on the money "good" but rather that the functions of money stricto sensu depend on the 'claims' on money.

Schumpeter does not confine himself to state that all the means used for paying can be assimilated to the current form of money stricto sensu, that is legal tender. His main point is that legal tender represents the ending rather than the initial ring in the chain of creation of purchasing power. This means that, as emerges from the actual working of "capitalist finance", monetary flows are governed by a "clearing system that cancels claims and debts and carries forward the differences - so that 'money' payments come in only as a special case without any particularly fundamental importance" (Schumpeter (1954), p.717; see also: ibid, pp.321 and 719-20; (1970), pp.126-28, 150, 209-11, 213-14). This 'bookkeeping' conception of the monetary system which is dealt with at a greater depth in the published (cf. Schumpeter (1970)) and the additional (cf. Schumpeter (1996)) chapters of the Theory of money and banking and which anticipates fundamental aspects of the current organization of the payment system, highlights bank creation of means of payments and the essential role of credit in the cyclical development 15 . Such a conception is not a radical new representation of the monetary system, but elaborates on J.S. Mill's intuitions and Wicksell's analytic work, and parallels

\footnotetext{
15 Cf. in particular: Schumpeter (1970), ch. VI and VII; and Schumpeterr (1996), ch. XIV. See also: Schumpeter (1996), Part I Appendix; Messori (1996).
} 
various aspects of Robertson's (1926) and Keynes' (1930) approaches. Schumpeter however improves the analytical framework of this monetary system (see below, secs. 3 and 4). In particular, he does not lock his analysis of bank behaviour in a 'pure credit' model, but admits that the amount of legal tender acts as a restriction to bank creation of means of payment by regulating the reciprocal links amongst the individual competing banks and between each bank and the central bank (see Messori 1996). Hence, Schumpeter's neglect of money as a stock and his related assimilation of money to credit have a more fundamental theoretical meaning than in Wicksell's monetary theory 16 .

Before examining the ways in which banks create means of payment, it is appropriate to analyze Schumpeter's definition of money (cfr. (1917-18), pp.57-65; engl. trans., pp.168-74). Money broadly speaking should include all those circulating elements which are accepted in exchange for goods and services, and should exclude all those liquid means which are not actually in circulation. On the basis of this definition, neither the liquidity held as reserve by banks or by non bank agents against future payments, nor the means of payment held as stock in order to cover other transactions or utilized for transfers of property rights, nor the means of payment ready to enter into circulation but temporarily hoarded can be calculated in the quantity of money (cf. ibid, pp. 67-8; engl. trans., pp.175-6; see also: Bousquet (1929), p. 1030). This makes the concept of 'quantity' of money unsteady and difficult to predict. It is enough to consider that the

16 This relates Schumpeter's monetary analysis to that stream of the "new Keynesian economics" centered on information asymmetries and on the connected imperfections in the capital market. The monetary theory of this new Keynesian stream is, in fact, limited to the credit flows (see Blinder-Stiglitz (1983); Greenwald-Stiglitz (1991) and (1993); and, for a critical assessment, Messori-Tamborini (1995)). 
amount of 'claims' on money, which are added during the cyclical evolution to the money in circulation in the stationary state, depends on the decisions and behavior of various economic agents; moreover, such an amount is prone to frequent variations also because of the wide spectrum of means of payment which may flow from circulation into non circulation, and viceversa (cf. Schumpeter (1970), pp. 232-36; cf. also: Shah-Yeager (1994), p. 454).

This last aspect is important in order to clarify the links between Schumpeter's monetary theory and the quantity theory of money. Schumpeter's definition of money implies that the quantity of money is by and large equal to the purchasing power used in each period by producers for taking possession of the services of the original factors (labor and land), or to the monetary income spent in the same period by the holders of such factors in the market of consumption goods. Given the sequence of exchanges in the markets of services and consumption goods (see below, section 3), the velocity of circulation of money is stable. Hence, if the sum of its components were exogenously determined, the quantity of money lato sensu would determine the absolute level of prices of the productive services and consumer goods without affecting their quantities and their relative prices. This would restore the traditional formulation of the quantity theory and, as a consequence, would imply the failure of Schumpeter's attempt to integrate money as capital into the process of economic development.

The point is that in the different phases of the cyclical development, a Schumpeter's component of money lato sensu is endogenously determined (see below, sec. 4). Therefore, Schumpeter's monetary theory becomes incompatible with two of the cornerstones of the quantity theory of money: the exogenous determination of money supply and the consequent causal relation 
between this quantity and the general level of prices. However, analogously to Wicksell ((1898), ch.5) Schumpeter (see e.g.: (1948); (1970), pp.48-53) streses that the 'fundamental equation', which is another cornerstone of the quantity theory of money and does not imply any causal link between its two sides, can still be valid without becoming a "tautology" (cf. Schumpeter (1917-18), p.78; engl. trans., p.183; (1970), pp. 282-83; cf. also Marget (1938), pp.19-22 and 91-2). Schumpeter's conclusion is that the 'fundamental equation' remains an important descriptive tool of monetary theory even if it asks for a sensible re-definition, compared to Fisher's traditional formulation, in order to be embodied in his framework.

In this paper it is not convenient to give details of the various features which the 'fundamental equation' can assume in Schumpeter's monetary theory 17 . The previous considerations are, however, sufficient for pointing out a few clear-cut aspects. Although it does not give a solution to all problems raised by the link between credit and money stricto sensu, Schumpeter's credit theory of money allows three crucial aspects of a 'dynamic' monetary theory to emerge: (i) monetary flows have 'real' effects since they act as capital, (ii) this presupposes a (partial) endogenization of the quantity of money, and (iii)this implies a criticism of the traditional formulations of the quantity theory of money.

\section{Money capital and economic development}

In order to better apprecia te Schumpeter's monetary analysis, it is useful to start with the following three assumptions: (1) the

17 It is sufficient to refer to Schumpeter (1917-18), sec. 4-8; (1970), pp. 239-46, 261-62, 280-83. See also Marget (1938), pp. 350-74 and 498-506; Marget (1942), pp. 115-19; Stolper (1943), pp. 89-90. 
economic system is in a stationary state, (2) the quantity of money is determined exogenously, and (3) the money endowment of the managers of the productive units satisfies the reproduction constraints of the stationary equilibrium 18 . Given these assumptions, the economic agents can only utilize existing money as a unit of account and as a medium of exchange; in that case, money does not affect transactions but it represents the "cloak of economic things"19. This does not mean, however, that monetary flows are unimportant for the sequence of exchanges of goods and productive services. Schumpeter's stationary state is not based on "simultaneous exchanges" but on a circulation of goods and services as well as of 'money' which takes place in a sequence, even if it reproduces itself on an unchanged pace from period to period (cf. Schumpeter (1912), pp.54-7; engl. trans., pp. 41-6; (1970), pp. 109-11; see also Graziani (1978), pp. 459-60; Oakley (1990), pp. 240-41).

Each period $(t)$ is opened by the monetary demand for the services of the original factors (land and labor) made by the

18 As touched upon above, the terms 'entrepreneur' and 'firm' are attributed respectively - to innovators and to innovative activities. Hence, the economic agents who manage the production processes in the stationary state are labelled 'managers' or 'administrators' of productive units which realize routine activities.

19 Cf. Schumpeter (1912), pp. 60-6; engl. trans., pp.46-52. Schumpeter adds that, in principle, the money functions as unit of account and medium of exchanges are separated (cf. also: (1908), p.289; (1970), pp.33-4). As a consequence, in the stationary state money could take the form of a credit means of payment, and money stricto sensu could confine itself to act as a "debtdischarging unit of account" (cf. De Vecchi (1995), p. 66). Following Schumpeter, I assume that the money circulating in the stationary state is money stricto sensu (from now on 'money') and not a 'claim' on money. Together with (1) and (3), this assumption also facilitates the determination of the quantity of money (see Schumpeter (1939), p. 546; (1954), pp. 704-5; (1970), p. 232-33). 
managers of the $m$ productive units, who hold a quantity of 'money' equal to the unchanging monetary proceeds realized in the previous period 20 . In the labor market the demand curve has a constant and unitary price elasticity, and the money wage rate ensures the full employment equilibrium. We have:

$$
\begin{array}{llll}
R_{S s}= & \text { M } & & \\
s s
\end{array}
$$

with: $\quad R_{s s}=\sum_{j=1}^{m} R_{j t-1} ; M=\sum_{j=1}^{m} M_{j t-1} ; N=\sum_{j=1}^{m} N_{j t} ; w_{s s}=w_{t}=$

$w_{t-1}$

and where $R_{j t-1}$ denotes the monetary proceeds realized by the productive unit $j$ at the beginning of the previous period $(t-1)$ and stored until the beginning of period $(t), R_{s s}$ the unchanging aggregate proceeds realized by the $m$ productive units in each period of the stationary state, $M_{j t-1}$ the quantity of 'money' that the productive unit $j$ carried over from $(t-1), M$ the unchanging amount of 'money' circulating in the economic system, $w_{t}$ the equilibrium money wage rate in $t$ which is unchanging over each period of the stationary state $\left(w_{s s}\right), N_{j t}$ the amount of labor

20 From now on I will exclusively refer to the services of labor since the analysis of the services of land would require further qualifications. Moreover, the level of aggregation of equation (1) below conceals that the productive units must replace the investment goods consumed in the current productions. It is worth noting, in this respect, that Schumpeter follows the Austrian representation of vertically integrated production processes; hence, Schumpeter cannot assimilate this replacement to the demand for the services of the original factors (e.g.: (1912), pp. 19-21 and 57-9; engl. trans., pp. 16-7 and 45-6). However, the Austrian representation of the production processes does not affect the analysis of the stationary state. The proof is that, in some passages (e.g.: (1970), pp. 286-9), Schumpeter refers to the opposite two-sector models without implications. Conversely, as it will be specified later, the assumption of vertically integrated productive processes plays an important role in the cyclical development. 
services hired by the productive unit $j$ in $t$, and $N$ the level of full employment.

As (1) shows, the advance of money income to labor (and land) services transfers the existing quantity of 'money' to workers (and landowners) who utilize it for carrying out their unchanging purchase of final goods. The supply of these goods is given by the output produced at the end of the previous period and held in stock by the $m$ productive units:

$$
w_{s s} N=\sum_{j=1}^{m} \quad p_{j s s} Q_{j s s}=R_{s s}=M
$$

with: $Q_{j s s}=Q_{j t-1} ; p_{j s s}=p_{j t} \quad \forall j=1,2, \ldots, \mathrm{m}$;

and where $Q_{j t-1}$ denotes the amount of the final good which is produced in $(t-1)$ and offered in $t$ by the unit $j$ and which is unchanging over each period of the stationary state $\left(Q_{j s s}\right), p_{j t}$ denotes the equilibrium market prices of this same good in periods $t$ which are also unchanging over each period of the stationary state $\left(p_{j s s}\right)$.

As (2) shows, the $m$ productive units instantly take again possession of their initial quantity of 'money' which will be used to finance their unchanging monetary demand for productive services at the opening of the next period. Moreover, during the current period, the $m$ productive units obtain that amount of factors which is necessary to carry out their production processes on an unchanged scale.

The representation of the working of the economy in the stationary state stresses that it is a 'synchronized' process; hence, the sequence of exchanges and production does not imply important changes with respect to a framework based on simultaneous transactions (cf. Schumpeter (1970), pp. 113-16). This sequence is, however, sufficient to point out that, in the aggregate, money represents the irreplaceable "claim ticket" to the world of productive services and goods. In the stationary process, 
the set of productive units must hold (unintentionally) the quantity of 'money' from each period to the following one; and, at the beginning of any given period, the 'money' held is essential for financing the purchase of the productive services, that is, for starting the transactions and for carrying out the current production. As a consequence, 'money' can act as a medium of exchange only because it acts as a monetary advance which allows for production processes to take place.

Such role of advance, although not being strictly equivalent to the function of money capital, constitutes a partial approximation of it. Schumpeter defines capital as a "fund of purchasing power" placed at disposal of entrepreneurs to allow the realization of their decided innovations (cf. (1912), pp. 165-74; engl. trans., pp. 11523; see also: Schumpeter (1939), p.129). In principle, this fund could be constituted by both 'money' and 'claims' on money. In fact, being added to the quantity of 'money' circulating in the stationary state, the typical form of this new fund is that of bank credit (see sec. 2 and below). Schumpeter infers from this that capital is a concept which is typical of economic development: "in an economic system without development there is [...] no 'capital'; or, otherwise expressed, capital does not fulfil its characteristic function" ((1912), p.172; engl. trans., p.121; see also: (1970), p.116). This suggests that, according to Schumpeter, money capital accomplishes the dual role of financing the purchasing of productive services and of re-allocating these services between the preexisting productive units of the stationary state and the innovative firms founded by the entrepreneurs. It is clear that the monetary advances in the stationary state fulfil the first role but not the second one. According to Schumpeter's previous passage, I can thus conclude that such advances act as 'potential' capital even without playing its full functions (see also Schumpeter (1970), pp. 283-8). 
These conclusions can be translated into current economic parlance by maintaining that Schumpeter's stationary state does not allow for a micro-foundation of money as capital. This statement is confirmed as soon as some features of the monetary advance in the stationary state are investigated. For example, it is clear that, given the logical priority of the monetary purchase of productive services with respect to any other transaction, it becomes arbitrary to assume that there is a given quantity of 'money' exogenously determined and endowed to the managers of the productive units. On the other hand, the possible reference to means of payment, endogenously created by bank lending, gives rise to new problems (see also above, n. 19). The banks would grant loans which would be risk free, and which would be paid back instantly by borrowers. Furthermore the latter, obtaining monetary proceeds equal to monetary costs from their unchanging productive activities, would have neither incentives nor the possibility to pay a positive interest on loans (cf. Schumpeter (1970), p. 299). This eliminates the typical features of debt contracts which can be brought back to the three following: (i) a time lag between the financing and its refunding, (ii) the consequent positive risk that (some of) the borrowers will default and (iii) the connected determination of a specific interest rate by the lender.

I think that Schumpeter excluded the concepts of credit and capital from the stationary state also in order to avoid this kind of problem $^{21}$. The fundamental reason of the author's choice is,

21 It is important to clarify that what has just been said does not contrast with Schumpeter's repeated statements that credit and interest penetrate into the stationary state and become permanent and important phenomena of the capitalist economic system (e.g.: (1912), p. 150; engl. trans., p. 104; (1970), p.300). As it clearly emerges from such statements, this is the result of previous development processes and of (speculative) excesses induced by innovations. In 
however, attributable to his wish for emphazising not only the links but mainly the analytical differences occurring between stationary state and cyclical development (cf. Schumpeter (1912), p. 151; engl. trans., p.105). Assuming that in the stationary state there is an exogenous quantity of 'money', Schumpeter can justify the lack of a capital market where debt contracts are designed and drawn up and where different interest rates are determined. On the other hand, by describing the stationary state as a period process, Schumpeter lays the bases for his criticism of the traditional definitions of capital. The result is that a complete analysis of money as capital requires a well organized capital market and, therefore, goes hand in hand with cyclical development. Such analysis, however, must start from the role of 'advance' played by money in the stationary process.

The process of cyclical development takes place in a sequence of exchanges similar to the period process of the stationary state $^{22}$. As stated earlier (see also equations (1) and (2)), at the end of each period of the stationary state, the only 'money' holders are the managers of the productive units, who plan to use the entire amount of this 'money' to purchase the services of the

order not to fall into the vicious circle which explains the development phenomenon by presupposing it (see also n. 7, point ii), my analysis of the stationary state is not based on a previous development process. Furthermore, I am referring to Schumpeter's two-phase cycle (or 'first approximation') and not to the four-phase cycle (or 'second approximation'). Without neglecting any essential aspect (cf. Stolper (1982), p. 45), in this way I exclude any speculative phenomenon which would lead to depression (see also: Schumpeter (1939), ch. 4).

22 As will result clearer below (see sec. 4), the crucial differences between the time sequences of the cyclical development and of the stationary state lay in the fact that the former cannot be reduced to an instantaneous process through the synchronization of exchanges and productions. 
original factors (here labor services) at the opening of the following period. In this framework, the introduction of an innovative activity does not alter the plans of the incumbent productive units. Even if the entrepreneurs were to identify with a subset of the old managers, the latter would anyway consider it convenient to associate the innovative production with their previous productive activity for they would expect the routine behaviours to be economically efficient until the innovative output will be supplied in the market of final goods 23 . It follows that the entrepreneurs, besides being devoid of services of the original factors and of investment goods, do not have any purchasing power and cannot obtain transfer of cash from the managers of the incumbent productive units. This implies that: (1) the accomplishment of the decided innovations and the consequent beginning of the cyclical development process presuppose the creation of means of payment in favour of the entrepreneurs; (2) such monetary means add to the 'money' circulating in the stationary state; (3) the bank system is the institution typically set up for the financing of entrepreneurial activities through the creation of new 'claims' on money 24 .

23 Schumpeter (e.g.: (1912), pp. 100-1; engl. trans., pp. 65-6) insists on the fact that the entrepreneur is a new figure, not characterized by her link with an old productive unit but by her capability to produce "other things" or "the same things by a different method". Schumpeter does not offer, however, an analytical justification on why the innovation should be embodied in a new firm. The explanation just suggested, which is also compatible with other passages by the author (see Schumpeter (1912), p. 216; engl. trans., pp. 136-37; (1939), pp. 946), aims to fill this gap.

24 Schumpeter stresses points (1)-(3) in several passages. E.g.: (1912), pp. 1049 and 141-44; engl. trans., pp. 69-71 and 96-8; (1913), pp. 57-62; (1917-18), pp. 104-5; engl. trans., pp.202-3; (1939), pp.110-11; 1970, pp.291-92. A large part of these quotations refer furthermore to my following analysis. In this analysis I 
An investigation on points (1)-(3) would raise a number of questions. That of point (3), in particular, would require an analytical and historical explanation of why Schumpeter ascribes a role of "venture" capitalist to banks. Here I confine myself to recalling that Schumpeter's analysis of bank behaviour is strongly affected by the German financial set-up at the beginning of this century, and that this analysis does not imply that the credit supply is infinitely elastic (see Schumpeter (1912), pp. 161-4; engl.trans., pp. 112-15; Messori (1996)). This possible investigation would not change, anyhow, the fact that the entrepreneurs utilize their money capital in order to take possession of the amount of the services of labor which are necessary for carrying out their innovative activity 25 . This implies that there is an additional demand for labor services compared to the level set in the stationary state which, in its turn, coincides with full employment. As a consequence, bank's creation of means of payment in favour of the entrepreneurs implies not only changes in the produced amount of investment and final goods but, primarily, changes in the absolute and relative prices and a re-allocation of productive services.

\section{The sequence in the cyclical development}

It is possible to formally sketch the sequence of exchanges, which characterizes the process of cyclical development (see also: Schumpeter (1970), pp. 292-93), by starting from the framework

\footnotetext{
will also offer some information concerning the allocation and spread of innovations through the reference to the "swarm" of entrepreneurs and to to the "imitation" processes (see sec. 4). In any case, I assume that the entrepreneurial activity always reaches a dimension sufficient to affect market prices

25 Let me recall that I am exclusively referring to the services of labor (see above, n.20). Moreover, I assume at first that the labor units are homogenous.
} 
of the stationary state, synthesized by equations (1) and (2) above. At the beginning of period $(t+1)$ in which entrepreneurs come on and obtain new purchasing power through bank financing, the managers of the incumbent productive units have, as a budget constraint, the unchanging monetary proceeds realized in the previous stationary state. It follows that, at the beginning of $(t+1)$, the monetary demand for labor services made by the set of productive units is still $R=M$; however, unlike in the previous periods of the stationary state, the aggregate monetary demand for labor services is increased by that of the entrepreneurs which is equal to $\sum_{k=m+1}^{n} L_{k t+1}$ - where $L_{k t+1}$ denotes the credit flow granted by a given bank to entrepreneur $k$. The adjustment between the increased monetary demand and the unchanged supply of labor services in the labor market implies an increase in money wages 26 , that is:

$$
M+L_{t+1}=w_{t+1} N \quad w_{t+1}>w_{s s}
$$

with: $L_{t+1} \equiv \sum_{k=m+1}^{n} L_{k t+1}$;

and where $w_{t+1}$ denotes the equilibrium money wage rate in $(t+1)$.

This increase in the money wage rate allows the new firms to start their innovative processes through the withdrawal of a part of the labor services from the incumbent productive units, that is:

\footnotetext{
26 Although Schumpeter refers to the traditional supply curve of the labor unit, which -at least in its first part- increases with the real wages (e.g.: (1912), pp. 27-8; engl. trans., pp. 22-3), Schumpeter's analysis requires that the labor supply becomes infinitely rigid to the predetermined full employment level. For a brief examination of the ad hoc arguments which may make Schumpeter's position coherent, see Messori (1987), p.147, nn. 12 and 13. Anyway I assume here that, in the two-phase cycle, this full employment condition is always realized.
} 


$$
\begin{aligned}
& M=w_{t+1} N_{o} \quad N_{o}<N \\
& L_{t+1}=w_{t+1} N_{n} \quad N_{n}>0
\end{aligned}
$$

with: $N_{o} \equiv \sum_{j=1}^{m} N_{j t+1} ; N_{n}=N-N_{o}$;

and where $N_{o}$ and $N_{n}$ denote the amount of labor services hired, respectively, by the set of the old productive units and by the set of entrepreneurs at the beginning of $(t+1)$.

The related increase in the total amount of money wages implies furthermore that, in the market of final goods, there is an equivalent increase in the aggregate monetary demand. Given that the supply of final goods is equal to the unchanged output produced by the incumbent units in the previous stationary state (period $t$ ), an increase in the price of those goods will follow. Confining the analysis to the aggregate leve 27 , we have:

$$
p_{t+1}=w_{t+1} N / Q_{s s}=w_{t+1} / \pi_{s s} \quad p_{t+1}>p_{s s}
$$

where $p_{t+1}$ and $p_{s s}$ denote the aggregate level of prices, respectively, in $(t+1)$ and in the stationary state, $Q_{s s}$ the aggregate level of output in the stationary state, and $\pi_{s s}$ the average productivity of labor services in the stationary state.

At the aggregate level, this price increase is proportional to that of the money wages; hence, the real wage rate remains unchanged $\left(w_{t+1} / p_{t+1}=w_{s s} / p_{s s}\right)$.

27 Schumpeter refuses the method of aggregates (see (1935), p.136; (1936), pp.154-5; (1939), pp.43-4; (1946c), p.210; (1970), p.269). My simplification is, therefore, arbitrary and contrasts with Schumpeter's analysis of the macroeconomic consequences of innovations (e.g. Schumpeter (1939), p. 144). I have resorted to this simplification because I have not yet specified the hypotheses concerning the time lags in the realization of innovations and their sectorial allocation. I have confined myself to assuming that the innovative activities have, since the beginning, a sensible macroeconomic impact (cf. n. 28). 
These changes in the absolute prices and in the allocation of the productive services are not free of consequences for the income distribution (see also Schumpeter (1996), ch. XV). It is sufficient to note that the incumbent productive units, being the only suppliers in the market of final goods, get monetary proceeds higher than the unchanged production costs so that they reach unexpected profits $\left(\rho_{o t+1}\right)$. Given (4) and (5), we have:

$$
\rho_{o t+1}=p_{t+1} Q_{s s}-w_{t+1} N_{o}=w_{t+1} N_{n}
$$

(4)-(6), however, do not point out all the macroeconomic and microeconomic changes of the first phase of the cyclical development to which Schumpeter refers by the term prosperity (or expansion). At least two other elements enter into the previous picture: the lengthening of the new production processes, and the appearance of "swarms" of entrepreneurs and imitators.

Innovations imply a lengthening of the new production processes (cf. Schumpeter (1939), p. 93; cf. also: ClemenceDoody (1950), p.9). Analogously to the productive units of the stationary state, the innovative firms utilize not only the labor services and the (here neglected) land services but also investment goods. In the vertically integrated production process which is typical of the "Austrian school" and of Schumpeter, investment goods are "potential" consumption goods (that is, intermediate goods). In the case of innovation, the investment goods are 'specific' to the new production processes and, unlike the homogeneous labor units (cf. n. 25), they cannot therefore be withdrawn from the incumbent productive units of the stationary state through an increased monetary demand. Hence, before producing the final goods, each innovative firm has to produce the intermediate goods necessary for producing its final good (see also: Amendola-Gaffard 1988). Let me assume, for sake of simplicity, that the production of the new intermediate goods 
requires only one standard production period, and that an additional standard period is sufficient to produce the final goods by combining these new intermediate goods with the labor services. As a consequence, innovative firms are able to end their innovative productions in two periods, and therefore they supply their final goods on the market at the opening of the third period (here, period $(t+3)$ ).

The lengthening of the innovative productions changes the above described picture of the prosperity phase 28 . This lengthening implies that, at the beginning of the second period of the innovative process (that is, at the beginning of $(t+2)$ ), entrepreneurs ask successfully for a new bank financing. Let me assume, for sake of simplicity, that (a) the set of the old productive units decides not to utilize the unexpected profits, $\rho_{o t+1}$, held in stock from the beginning of $(t+1)$, to increase its monetary demand for labor services, that (b) such a decision is "common knowledge", and that (c) the amount of labor units, required by the production of the new intermediate goods in $(t+1)$, is equal to that required by the combination which produces, in $(t+2)$, the new final goods. Assumptions (a)-(c) imply that, in ( $t+2)$, the amount of the entrerpreneurs' demand for financing is equal to that of the previous period, that is $L_{t+2}=L_{t+1}$. Hence, the equilibrium in the labor market does not change, that is:

$$
M+L_{t+2}=w_{t+1} N
$$

$$
M=w_{t+1} N_{o} \quad N_{o}<N
$$

bis)

\footnotetext{
28 This is why I stated earlier (see n. 20) that the Austrian analysis of the production process plays an important role in Schumpeter's cyclical development. An opposite thesis is maintained by various critics (e.g.: Stolper (1982), p. 37).
} 


$$
L_{t+2}=w_{t+1} \quad N_{n} \quad N_{n}>0
$$

Equations (3 bis) and (4 bis) and the lengthening of the innovative productions imply, however, that workers undergo a "forced savings" 29 . Regarding this last point, it is sufficient to note that, given the unchanged total amount of money wages and hence the unchanged monetary demand by workers (cf. points (a)-(c) above), in ( $t+2)$ the availability of final goods is decreased compared to the previous period. The old productive units continue to be the only suppliers of final goods, but their output has decreased at the end of $(t+1)$ due to bank financing of the innovative processes and the related withdrawal of labor services by the entrepreneurs. As a consequence, remaining at the aggregate level and assuming full employment (cf. n.26), at the beginning of $(t+2)$ the price of the final goods marks a new increase so that the unchanged amount of money wages leads to a fall in real wages. We have (see also equation 5):

$$
p_{t+2}=w_{t+1} N / Q_{t+1}=w_{t+1}\left(1 / \pi_{s s}+N_{n} / \pi_{s s} N_{o}\right)
$$

with: $Q_{t+1}<Q_{s s}$; and $p_{t+2}>p_{t+1}$;

29 An accurate definition of "forced savings" is given by Machlup ((1943), pp. 27-8). Schumpeter seems to swing between two extreme positions: at times he attributes great importance to this phenomenon (e.g. (1912), pp. 155-56; engl. trans., pp. 108-9; (1917-18), pp. 92-3; engl. trans., pp. 193-94), at others he considers the reference to it misleading (cf. (1939), p. 112n). In fact, Schumpeter does not modify his position over time. In Schumpeter's development process, the "forced savings" may indicate the fall in the purchasing power of the receivers of fixed incomes as well as of a subset of managers of the old productive units (and, in a subordinate position, a fall in the real wages of a subset of workers). However, Schumpeter's "forced savings" never indicate the fall in the total amount of real wages (cf. also Schumpeter (1996), ch. XV). The limit of this position, which is softened only in Schumpeter ((1954), pp. 1115$16)$, is due to the underestimation of the temporary effects that the lengthening of the innovative productions has on the income distribution. 
and where $Q_{t+1}$ denotes the aggregate level of output produced at the end of $(t+1)$ and sold at the beginning of $(t+2)$, and $p_{t+2}$ denotes the aggregate level of prices in $(t+2)$.

Conversely, continuing to be the only supplier, the set of the old productive units gets the same amount of profits obtained in the previous period, that is

$$
\begin{aligned}
& \quad \rho_{o t+2}=p_{t+2} Q_{t+1}-w_{t+1} N_{o}=w_{t+1} N_{n} \\
& \text { (6 bis) } \\
& \text { with: } \rho_{o t+2}=\rho_{o t+1}
\end{aligned}
$$

The analysis made so far implies that the prosperity phase should have to finish at the beginning of period $(t+3)$, when the innovative output is offered in the market of final goods. Given that the entrepreneurs realize their expectations ${ }^{30}$, their amount of final goods would more than compensate the negative difference between the current and the stationary state output realized by the old productive units. Therefore, at the aggregate level, the price of the final goods would decrease, the set of the old productive units would suffer losses, the entrepreneurs would attain their expected profits (gross of the financial charges), and the unchanged amount of money wages would imply a real wage rate even higher than that in force in the stationary state and in $(t+1)$. We would have:

$$
p_{t+3}=w_{t+1} N / Q_{t+2}=w_{t+1} N /\left(\pi_{s s} N_{o}+\pi_{n} N_{n}\right)
$$

with: $Q_{t+2}>Q_{t+1} ; \quad p_{t+3}<p_{t+2} ;$ and $w_{t+1} / p_{t+3}>w_{t+1} / p_{t+1}=w_{s s} /$ $p_{s s}>w_{t+1} / p_{t+2}$

\footnotetext{
30 It is a condition which is always fulfilled in Schumpeter's model of 'first approximation'. This strenghtens Schumpeter's criticism to those authors that, like Keynes (1936), reserve a role of deus ex machina to the expectations (e.g.: Schumpeter (1936), p. 154n; (1939), p.55).
} 
and where $\pi_{n}\left(>\pi_{o}\right)$ denotes the average productivity of labor services in the innovative productions;

$$
\begin{aligned}
& \rho_{o t+3}=p_{t+3} Q_{o t+2}-w_{t+1} N_{o}= \\
& =w_{t+1} N_{o} N_{n}\left(\pi_{s s}-\pi_{n}\right) /\left(\pi_{s s} N_{o}+\pi_{n} N_{n}\right) \\
& \rho_{n t+3}=p_{t+3} Q_{n t+2}-w_{t+1} N_{n}= \\
& =w_{t+1} N_{o} N_{n}\left(\pi_{n}-\pi_{s s}\right) /\left(\pi_{s s} N_{o}+\pi_{n} N_{n}\right)
\end{aligned}
$$

with: $\rho_{o t+3}<0$ and $\rho_{n t+3}>0$ since $\pi_{s s}<\pi_{n} ; Q_{o t+2}+Q_{n t+2}=Q_{t+2}$; and where $Q_{o t+2}\left(\equiv \pi_{s s} N_{o}\right)$ and $Q_{n t+2}\left(\left(\equiv \pi_{n} N_{n}\right)\right.$ denote the total level of output produced at the end of $(t+2)$, respectively, by the $m$ incumbent productive units and by the $(n-m)$ innovative firms, and $\rho_{o t+3}$ and $\rho_{n t+3}$ denote the monetary profits realized in $(t+3)$, respectively, by these same two sets of producers.

It must be noted, however, that equations (8) and (9) do not consider that the innovative activities are not restricted to those realized by the first entrepreneur(s) but take place in "swarms" (cf. e.g.: Schumpeter (1912), pp. 334-42; engl. trans., pp. 223-31). Taking into account this aspect is crucial since it marks the shift from the aggregate to the microeconomic analysis. The problem is that this shift runs the risk of making Schumpeter's model so 'open' as to become analytically intractable. Therefore, it is worth introducing some simplifications and, then, describing informally a plausible working of the economic system.

\section{The 'swarm' of innovations: some microeconomic implications}

In order to analyze the 'swarm' of innovations, I assume that: (i) the first and limited group of entrepreneurs, which starts innovative processes at the beginning of period $(t+1)$, operates in specific sectors of the economic system; (ii) this group opens the way to a second and broader group of entrepreneurs that, in $(t+2)$, 
undertakes a modified version of (part of) the innovative processes under way in order to adapt them to the various economic sectors which are close to the innovative ones 31 ; (iii) the expected profitability of innovations pushes, in $(t+3)$, a first group of imitators, which operates in the numerous sectors by now touched by the initial or by the induced innovations, to replace their old activities of the stationary state with the new processes; (iv) in $(t+3)$ the old productive units, which continue to operate routinely in the sectors - directly or indirectly - touched by the innovations and by the first imitations, suffer actual losses so that a second group of imitators is pushed to undertake imitative processes at the beginning of $(t+4)$.

The reference to the four groups of producers sub (i)-(iv) highlights some microeconomic results and explains why the prosperity phase does not finish in $(t+3)^{32}$. The assumption, according to which the innovations are concentrated in specific economic sectors, implies that, at the beginning of period $(t+1)$, there is not a generalized increase in money wages but an increase in the money wage rates of the labour units hired in these sectors, that is in the innovative sectors (see instead equation 3 above). Given the variance in households' consumption, this leads to increases in the prices of some final goods but not of others (see instead equation 5 above). It follows that there is a change in the relative prices of final goods and services and, given the

\footnotetext{
31 It is possible to denominate these later innovations as induced innovations. In this paper I do not enter into Schumpeter's intuitable explanation of why the induced innovations are achieved more easily and can involve, therefore, a broader group of entrepreneurs than the initial ones.

32 The analysis of these behaviors requires the dimination of the previous simplification concerning the perfect omogeneity of the labor units. For what follows, see also: Schumpeter (1996), chs. XIV and XV.
} 
diversification of the activities in the stationary state, a redistribution of the monetary proceeds within the set of the old productive units. In particular, if they do not attain adequate increases in the monetary demand for their final goods, the old productive units operating in the innovative sectors or in those contiguous to the innovative sectors may suffer losses; and the workers, employed in productions 'remote' from the innovative sectors and hence with unchanged money wages, may suffer a fall in their real wages (see instead equation 6 above). The undertaking of induced innovations implies that, in $(t+2)$, the number of innovative sectors as well as the labor units with increasing money wage rates broaden. This accentuates the changes in the relative prices of goods and services as well as the income redistribution within the set of workers and within the set of the old productive units.

Finally, the progressive spread of the imitative processes may imply that, in $(t+3)$, in $(t+4)$, and in $(t+5)$ the new supplies of final goods produced -respectively- by the first innovators (see above, point i), by the second group of entrepreneurs (see above, point ii), and by the first group of imitators (see above, point iii), do not lead to an increase in the aggregate output (no matter how measured) and/or to a fall in the prices of these goods.

As regards to $(t+3)$, it must be recalled that the second group of entrepreneurs has started her two-period innovative processes in $(t+2)$ and will offer her final goods only at the beginning of $(t+4)$; moreover, at the beginning of $(t+3)$, the amount of money wages undergoes an increase because a first group of imitators resorts to bank lending and starts the new productions in the innovative sectors or in those contiguous to innovative sectors. Hence, at the beginning of $(t+3)$, the amount of new final goods supplied by the first innovators can be more than countervailed by (a) the lack of supply by the second and larger group of 
entrepreneurs, and by (b) the increased monetary demand for final goods which follows from the increase in money wages. As regards to $(t+4)$, it must be recalled that the first group of imitators just mentioned is now achieving his lengthened production processes, and will offer the new output of final goods only at the beginning of period $(t+5)$; moreover, at the beginning of $(t+4)$, there is a new increase in the amount of money wages because a second group of imitators resorts to bank lending and starts the new production processes. If the first and the second groups of imitators are sufficiently large in number, their withdrawal of labor services at the beginning of $(t+3)$ and $(t+4)$ with the consequent lack of supply and increase in money wages at the beginning of $(t+4)$ can more than countervail the supply of final goods by the first innovators and by the second group of entrepreneurs. And a similar reasoning could apply to $(t+5)$.

If these possible results come true, there is a common feature in the periods of the cyclical development analyzed so far: in all these periods, the undertaking and implementation of innovative or imitative processes dominate the lagged outcome of previous innovative or imitative processes so that the aggregate output of final goods either decreases or increases less than the increase in the amount of money wages, and prices raise. Consequently the bank financing, required to realize these new processes, not only creates additional 'claims' on money but also introduces in the economic system an amount of purchasing power that, at the prices of the stationary state, exceeds the decreased supply of final goods. Schumpeter ((1912), p.147; engl. trans., p.101) restates point (2) by maintaining that 'the credit structure projects [...] beyond the existing commodity basis". As I have already noted, this determines an increase in prices (of the majority) of the final goods. This increase can be defined as "credit inflation". It is worth stressing that we are dealing with a temporary inflation because it is only due to the lengthening of the innovative and 
imitative processes and to the related time lag between the starting of these processes and their output of final goods. In this last respect, it is worth stressing that the output of the new processes more than compensates for the previous surplus of purchasing power (cf. also Schumpeter (1996), ch. XIV).

This temporary inflation emphasizes that, by falling into debt with banks, the entrepreneurs and their imitators become indebted with the whole society so that, at least from the economic point of view, the settlement of their debts does not end in the repayment to lenders of the principal and of the contractual interests, but it also requires the refund of the final goods withdrawn from the circular flow through the withdrawal of labor services. Therefore, by anticipating the money capital, the banking system plays a role of "social accountant": it issues a "claim ticket" which enables entrepreneurs -differently from any other economic agent- to buy before selling. This means that the banking system issues, on behalf of the economic system, that "claim" which is necessary to realize the decided innovations and imitations (cf. Schumpeter (1912), pp. 158-59 and 110; engl. trans., pp. 110-11 and 73-4; see also: (1913), pp. 57 and 61-3; (1917-18), p.109; engl. trans., pp.205-6; (1970), pp. 125-26 and 149-54).

It is important to stress the temporary character and the economic functions of credit inflation. As the previous analysis shows, this inflation cannot be interpreted as a distortion in the working of the economic system which could be avoided or corrected by means of a restrictive monetary policy (cf. Schumpeter (1925b)), but it has to be considered as a necessary consequence of the redistributive mechanisms which are at the basis of economic development and which gradually spread to consumers as a whole (see below). Therefore, in contrast with Keynes (1923), Schumpeter (e.g. (1925a) and (1927a)) maintains that any attempt to stabilize the general level of prices, in order to 
avoid the credit inflation in a two-phase cycle, would have the undesired effect of preventing any development and of binding the economic system to the stationary state or to exogenous growth $^{33}$. Schumpeter adds that price swings are distorsionary, and hence must be controlled and corrected, only when they cease to be one of the normal consequences of the innovative processes and become the result of speculative behaviors which are typical of the four-phase cycle.

These last statements will become more evident if the turning point, which divides the prosperity from the recession phase of Schumpeter's two-phase cycle, is specified. Due to the lengthening of the new production processes, Schumpeter's prosperity phase is characterized by a decrease in the available amount of final goods and/or by an increase in the aggregate level of prices ${ }^{34}$. Hence, there is the turning point in Schumpeter's two-phase cycle when the amount of final goods produced through the innovative or imitative processes more than compensates for the increase of money wages and for the lack of supply of final goods due to the implementation of other imitative

\footnotetext{
33 This also helps to pointing out the important differences which divide the cyclical models daborated, respectively, by Schumpeter and by Hayek (e.g., 1931). The analytical structure of the these two models is similar in many respects. However, according to Hayek, the bank financing of the lengthening of production processes does not only prime a disequilibrium cycle but it also causes a distorsion in the optimal working of the economic system.

34 It is worth recalling that the decrease in the amount of final goods and the increase in the level of their prices do not perfectly coincide. The aggregate level of prices can continue to increase even if the amount of final goods produced and supplied increases; it is sufficient that this last increase is more than compensated by the increase in the amount of money wages. I neglect this analytical problem, which is completely overlooked by Schumpeter too.
} 
processes by old productive units which were still tied to routine behaviors. This means that the aggregate supply of final goods begins to increase continuatively and their prices to decrease continuatively 35 . According to Schumpeter, this implies that credit inflation lasts and prosperity gives way to the the second cyclical phase, called recession. The turning point in the two-phase cycle is helped by the self-deflation process which is induced by the progressive settlement of the debts to the banks by the innovators and by (a part of) the imitators (cf. Schumpeter (1912), pp. 158-9 and 345; engl. trans., pp. 110-11 and 233-34; (1939), pp. 133-7; (1970), pp. 293-97).

The recession phase tends to flow into a neighborhood of equilibrium in which the 'claims' on money, introduced in the economy in order to finance innovations and imitations, are no longer in circulation because they have been returned to banks which, therefore, first created them and now 'destroy' them (cf. Schumpeter (1970), pp. 188 and 194). If exogenous increases of the 'money' supply are excluded, in the economic system there will remain the quantity of 'money' already circulating in the initial stationary state (ivi, p. 296). However, at this stage such 'money' is differently allocated amongst the economic agents. The old productive units, which were not able to imitate any innovation and were turned out of the market during the process of recessive adaptation, suffered losses and gave up 'money' flows to

35 This is one of the differences between Schumpeter's and Wicksell's (and A. Hahn's) analysis (see also: Bellofiore (1992)). In Wicksell's disequilibrium framework, bank creation of means of payment des not induce productive innovations and leads to repeated increases in the general level of prices, so giving rise to a cumulative inflation process (see also Schumpeter (1917-18), pp. 93-5; engl. trans., pp. 194-95; (1939), pp. 604-5; (1954), p. 1118). As a consequence, among other things, Schumpeter's position strenghtens Wicksell's criticism of the quantity theory of money. 
innovators and to the first groups of imitators, who monetized, in this way, heir profits gross of financial charges. These profits from innovation and imitation are nevertheless temporary, and the new income produced is gradually spread over the economic system.

Here I do not investigate Schumpeter's analysis of the recession phase and of the related process of recessive adaptation. Given the previous assumptions, and in particular the unchanged amount of 'money' with respect to the initial stationary state, I limit myself to underline few implications. As in the case of the temporary increase in prices due to "credit inflation" during prosperity (see above), Schumpeter does not give any negative connotation to recession: as just stated, this latter phase fulfils the function of spreading the results of innovations to the economic system, by making the prices to fall and by transferring the increased income to the households. According to Schumpeter (e.g. (1912), pp.348-49; engl. trans., pp.236-37; (1939), pp. 142-3), recessions thus represents a physiological element of economic development Let me assimilate, for sake of simplicity, the reached neighborhood of equilibrium to a new stationary state. We have (cf. also equations 1,2 , and 5):

$$
\begin{aligned}
& R_{s s}=M=w_{s s} N \\
& w_{s s} N=p_{s^{\prime} s^{\prime}} Q_{s^{\prime} s^{\prime}}
\end{aligned}
$$

with: $Q_{s^{\prime} s^{\prime}}>Q_{s s} ; p_{s^{\prime} s^{\prime}}<p_{s s}$ so that $w_{s s} / p_{s^{\prime} s^{\prime}}>w_{s s} / p_{s s}$;

where $Q_{s^{\prime} s^{\prime}}$ and $p_{s^{\prime} s^{\prime}}$ denote, respectively, the aggregate level of output and the aggregate level of prices in the final stationary state.

Before concluding the analysis of Schumpeter's model of cyclical development, it is worth stressing that its two-phase cycle can hardly be assimilated to the standard representation of a cycle fluctuating around a trend (cf. Schumpeter (1939), pp.207 and 
223). Moreover, Schumpeter makes use of quite idiosyncratic labels. The phase, which is called prosperity (or even expansion) and which is normally identified with the upward cyclical phase, is characterized by interperiod decreases in the aggregate output of final goods and/or by interperiod increases in their prices whereas the phase, which is called recession and which is normally identified with the downward cyclical phase, is characterized by interperiod increases in the aggregate output of final goods and/or by interperiod decreases in their prices until the attainment of a new stationary state. By roughly illustrating these changes respectively- in the aggregate output of final goods and in their prices, Figures 1 and 2 point immediately out the 'oddity' of Schumpeter's two cyclical phases. 


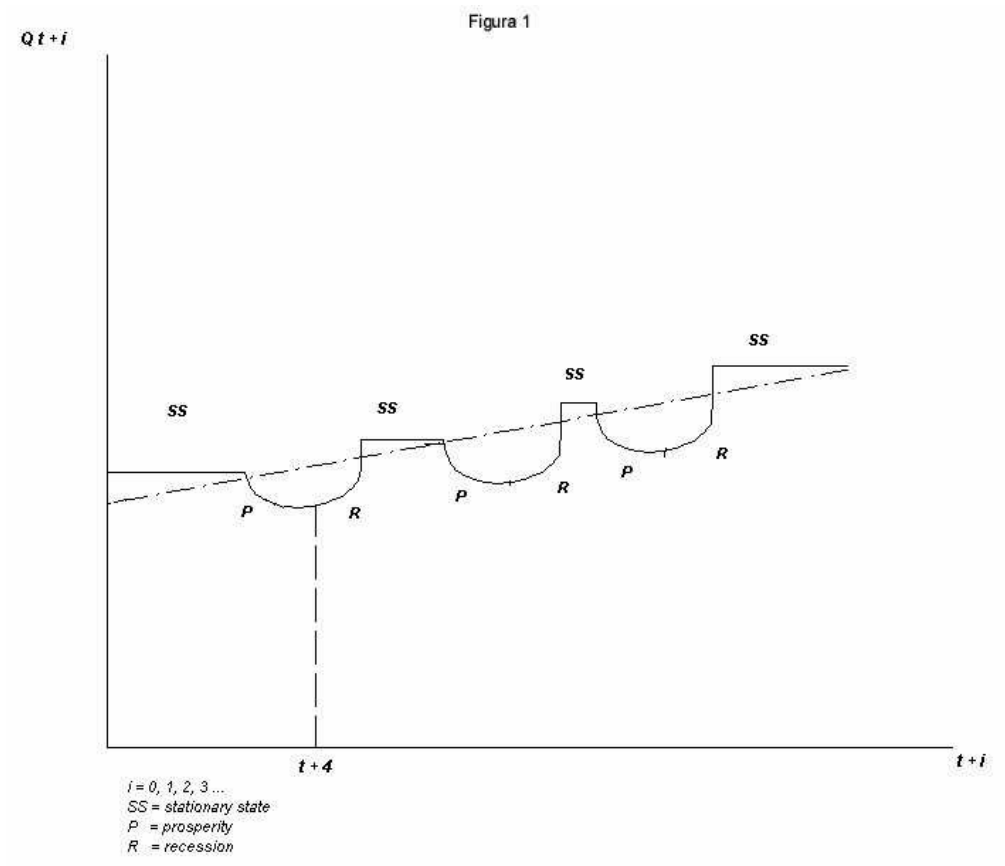




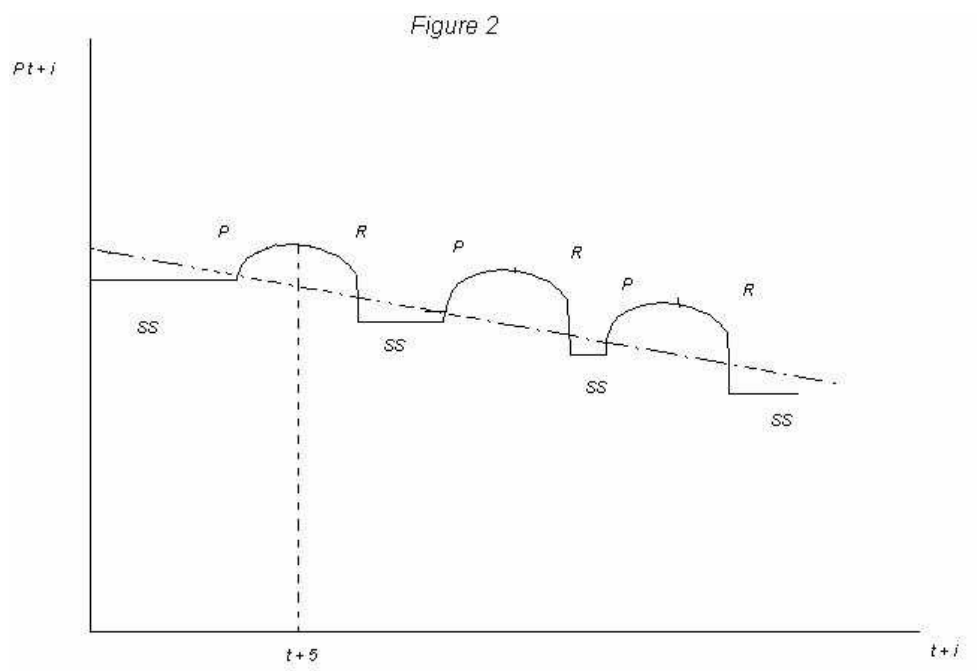

$i=0,1,2,3 \ldots$
$S S=$ stationary state

$P=$ prosperity 


\section{Conclusions}

Schumpeter's analysis of the two-phase cyclical development leaves other more analytical problems still unsolved. For example, some commentators have underlined that the temporal swinging between 'swarm' of entrepreneurs and lack of innovations is justifiable only by means of ad hoc hypothesis (cf. Kuznets (1940), pp. 262-4). Other commentators have shown that, by modifying a few assumptions, the innovative processes generate cyclical movements which are very different from Schumpeter's two-phase or four-phase cycle (cf. Brouwer (1991)). Others have maintained that the unilateral reference to innovations does not explain the periodic swinging of cyclical phases (e.g.: Tobin (1991), p.xi). Others have pointed out Schumpeter's too sketchy analysis of the turning point from the prosperity to the recession phases (e.g.: Oakley (1990), pp. 182-3). Although the close examination of each of these problems is preminent in order to reach an adequate reconstruction of the Schumpeterian framework, in this paper it is not possible to deal with such a task $^{36}$.

The overlooking of the limits which characterize the Schumpeterian model of the two-phase cyclical development, does not represent, however, the main weakness of the present paper.

\footnotetext{
36 Schumpeter himself acknowledges the importance of the listed problems. For example, Schumpeter ((1912), p. 347; engl. trans., p. 235) ponders for a long time on the reasons for "why other entrepreneurs seeking credit do not always step into the place of those liquidating their indebtedness"; and even if he stresses the importance to explain the occurrence of the "alternating phases" of prosperity and the recession, Schumpeter recognizes that "there is nothing in the working of our model to point to periodicity in the cyclical process economic evolution" (cf. (1939), p. 143). Furthermore, it is undeniable that Schumpeter's analysis of the working of the economic system in the cyclical development is so rich as to result often inaccurate.
} 
It is sufficient to recall that, even if it is dedicated to Schumpeter's credit theory of money, this paper does not specify the form of the debt contract between banks and entrepreneurs (or imitators) during the prosperity phase. The fact is that the determination of the debt contract design cannot be achieved through a simple summing up of the few pages which Schumpeter dedicates to the subject. As I show in a paper centered on this particular but crucial aspect of Schumpeter's credit theory of money (cf. Messori 1996), Schumpeter's analysis leaves various problems such as the objective-function of the individual banks, the determination of interest rates, and the role played by the credit demand and supply curves, unsolved. These limits do not cancel the fact that Schumpeter ((1912), (1939), (1970), and (1996)) elaborates a more complete and stimulating theory of bank behavior than Wicksell's (1898), Robertson's (1926), and Keynes' (1930) path-breaking analyses. 


\section{Bibliography}

Amendola, M., Gaffard, J.L. (1988), The innovative choice, Oxford: Blackwell.

Augello, M.M. (1990), Joseph Alois Schumpeter. A reference guide, Berlin: Springer-Verlag.

Bellofiore, R. (1992), "Monetary macroeconomics before the 'General theory'. The circuit theory of money in Wicksell, Schumpeter and Keynes", Social Concept, n.2.

Blinder, A., Stiglitz, J.E. (1983), "Money, credit constraints and economic activity", American Economic Review, 73, May, 297302.

Bousquet, G.-H. (1929), “L'oeuvre scientifique de quelques économistes étrangers: Joseph Schumpeter", Revue d'Economie Politique, 43, 1017-49.

Brouwer, M. (1991), The Schumpeterian puzzle. Technological competition and economic evolution, New York: Harvester Wheatsheaf.

Clemence, C.V., Doody, F.S. (1950), The Schumpeterian system, Cambridge Ma.: Addison-Wesley.

De Vecchi, N. (1993), Entrepreneurs, institutions and economic change. The economic thought of J.A. Schumpeter (1905-1925), Aldershot: E. Elgar.

Earley, J.S. (1983), "Schumpeter's theory of money, credit, and cycles: A second approximation", Working Paper Series, n.71, University of California, Riverside.

Graziani, A. (1977), "Il processo capitalistico di J.A. Schumpeter", in J.A. Schumpeter, Il processo capitalistico. Cicli (Italian 
edition of the abridged version of Business cycles 1964), Torino: Borignhieri.

Graziani, A. (1978), "Il Trattato sulla moneta di J.A. Schumpeter", in Scritti in onore di Giuseppe De Meo, vol.I, Roma: Facoltà di Scienze Statistiche.

Graziani, A. (1982), "L'analisi marxista e la struttura del capitalismo moderno", in Storia del marxismo, vol. 4, Torino: Einaudi.

Greenwald, B., Stiglitz, J.E. (1991), "Towards a reformulation of monetary theory: competitive banking ", The Economic and Social Review, 23.

Greenwald, B., Stiglitz, J.E. (1993), "New and old Keynesians", Journal of Economic Perspectives, 7, 23-44.

Hahn, A. (1920), Volkswirtschaftliche Theorie des Bankkredits, Tübingen: J.C.B. Mohr.

Hayek, F.A. (1931), Prices and productions, London: Routledge \& Kegan, 2d ed., 1935.

Hicks, J.R. (1935), "A suggestion for simplifying the theory of money", Economica. Reprinted in: J.R. Hicks, Critical essays in monetary theory, Oxford: Claredon Press, 1967.

Hicks, J.R. (1967), "The two triads", in J.R. Hicks, Critical essays in monetary theory, cit..

Hicks, J.R. (1982), "The foundations of monetary theory", in J.R. Hicks, Money, interest and wages, Cambridge Ma.: Harvard University Press.

Hicks, J.R. (1989), A market theory of money, Oxford: Claredon Press. 
Keynes, J.M. (1923), A tract on monetary reform, London: MacMillan.

Keynes, J.M. (1930), A treatise on money, 2 vol., London: MacMillan.

Keynes, J.M. (1936), The general theory of employment, interest, and money, London: Macmillan.

Klausinger, H. (1990), “The early use of the term 'veil of money' in Schumpeter's monetary writings - A comment on Patinkin and Steiger", Scandinavian Journal of Economics, 92, 617-21.

Kuznets, S. (1943), "Schumpeter's business cycles", American Economic Review, 30, 257-71.

Machlup, F. (1943), "Forced or induced savings: An exploration into its synonyms and homonyms", Review of Economic Statistics, 25, 26-39.

Marget, A.W. (1938), The theory of prices, vol.I, New York: Prentice Hall.

Marget, A.W. (1942), The theory of prices, vol.II, New York: Prentice Hall.

Marget, A.W. (1951), "The monetary aspects of the Schumpeterian system", Review of Economics and Statistics. Reprinted in: Schumpeter, social scientist,.edited by S.E. Harris, Cambridge Ma.: Harvard University Press.

Messori, M. (1987), "L'offre et la demande de crédit chez Schumpeter", Cahiers d'Economie Politique, n.13, 131-52.

Messori, M. (1996), "Schumpeter's analysis of the credit market", mimeo 
Messori, M. (1997), "The trials and misadventures of Schumpeter's treatise on money", History of Political Economy, 29, 639-73.

Messori, M., Tamborini, R. (1995), "Fallibility, precautionary behaviour, and the new Keynesian monetary theory", Scottish Journal of Political Economy, 42, 443-64.

Oakley, A. (1990), Schumpeter's theory of capitalist motion. A critical exposition and reassessment, Aldershot: E. Elgar.

Reclam, M. (1984), J.A. Schumpeter's 'credit' theory of money, University of California, Riverside.

Robertson, D.H. (1926), Banking policy and the price level, London: King \& Son.

Robertson, D.H. (1940), "Mr Keynes and the rate of interest", in D.H. Robertson, Essays in monetary theory, New York: Staples Press.

Schumpeter, J.A. (1908), Das Wesen und der Hauptinhalt der theoretischen Nationalökonomie, Leipzig:Duncker \& Humblot.

Schumpeter, J.A.(1910), "Über das Wesen der Wirtschaftskrisen", Zeitschrift fürVolkswirtschaft, Sozialpolitik und Verwaltung, 19, 271-325.

Schumpeter, J.A.(1912), Theorie der wirtschaftlichen Entwicklung, 2d ed., München und Leipzig: Duncker \& Humblot, 1926. Engl.ed. The theory of economic development, New York: Oxford University Press, 1934.

Schumpeter, J.A. (1913), "Zinsfuss und Gelverfassung", Jahrbuch der Gesellschaft Österreichischer Volkswirte. Reprinted in: Schumpeter (1952).

Schumpeter, J.A. (1917-'18), "Das Sozialprodukt und die Rechenpfennige: Glossen und Beiträge zur Geldtheorie von 
heute", Archiv für Sozialwissenschaft und Sozialpolitik. Reprinted in: Schumpeter (1952). Engl.trans. in International Economic Papers, 1956, 148-211.

Schumpeter, J.A. (1925a), "Kreditkontrolle", Archiv für Sozialwissenschaft und Sozialpolitik. Reprinted in: Schumpeter (1952).

Schumpeter, J.A. (1925b), "Oude en nieuwe bankpolitiek", Economisch-Statistische Berichten, 10, 552-4, 574-77, 600-1. Engl. trans. in Schumpeter's in the History of ideas, edited by Y. Shionoya e M. Perlamn, Ann Arbor: University of Michigan Press, 1994.

Schumpeter, J.A. (1927a), "Die goldene Bremse an der Kreditmaschine. Die Goldwaehrung und der Bankkredit", Koelner Vortraege, vol.I Die Kreditwirtschaft. Reprinted in: Schumpeter (1952).

Schumpeter, J.A. (1927b), "The explanation of the business cycles", Economica. Reprinted in: Schumpeter (1951b).

Schumpeter, J.A. (1928), "The instability of capitalism", Economic Journal. Reprinted in: Schumpeter (1951b).

Schumpeter, J.A. (1935), "The analysis of economic change", Review of Economic Statistics. Reprinted in: Schumpeter (1951b).

Schumpeter, J.A. (1936), "J.M. Keynes General theory of employment, interest and money", Journal of the American Statistical Association. Reprinted in: Schumpeter (1951b).

Schumpeter, J.A. (1937), "Preface", in Japanese trans. of Schumpeter (1912). Reprinted in: Schumpeter (1951b). 
Schumpeter, J.A. (1939), Business Cycles: A theoretical, historical and statistical analysis of the capitalist process, 2 vol., New York: McGraw-Hill, 1939.

Schumpeter, J.A. (1943); "Capitalism in the postwar world", in S.E. Harris, Postwar economic problems, New York. Reprinted in: Schumpeter (1951b).

Schumpeter, J.A. (1946a), "Capitalism", in Encyclopaedia Britannica. Reprinted in: Schumpeter (1951b).

Schumpeter, J.A. (1946b), "John Maynard Keynes: 1883-1946", American Economic Review. Reprinted in: Schumpeter (1951a).

Schumpeter, J.A. (1946c), "The decade of the twenties", American Economic Review. Reprinted in: Schumpeter (1951b).

Schumpeter, J.A. (1948), "Irving Fisher's econometrics", Econometrica. Reprinted in: Schumpeter (1951a).

Schumpeter, J.A. (1951a), Ten great economists, from Marx to Keynes, New York: Oxford University Press.

Schumpeter, J.A. (1951b), Essays of J.A. Schumpeter, edited by R.V. Clemence, Cambridge Ma.: Addison-Wesley.

Schumpeter, J.A. (1952), Aufsätze zur Ökonomischen Theorie, edited by E. Schneider e A. Spiethoff, Tübingen: J.C.B. Mohr.

Schumpeter, J.A. (1954), History of economic analysis, edited by E. Boody Schumpeter, New York: Oxford University Press.

Schumpeter, J.A. (1970), Das Wesen des Geldes, Göttingen: Vandenhoeck \& Ruprecht.

Schumpeter, J.A. (1996), Il trattato sulla moneta: capitoli inediti, edited by L. Berti and M. Messori, Napoli: ESI.

Shah, P.J. e Yeager, L.B. (1994), "Schumpeter on monetary determinacy", History of Political Economy, 26, 443-64. 
Stolper, W.F. (1943), "Monetary equilibrium and business cycle theory", Review of Economic Statistics, 25, 88-92.

Stolper, W.F. (1982), "Aspects of Schumpeter's theory of evolution", in Schumpeterian Economics, edited by H. Frisch, New York: Praeger.

Tobin, J. (1991), "Foreword", in E. März, Joseph Schumpeter. Scholar, teacher and politician, New Haven: Yale University Press (ed.or. ted.: 1983).

Walras, L. (1898), Etudes d'économie politique appliquée. Théorie de la production de la richesse sociale, Lausanne: Corbaz, 1936.

Walras, L. $\left(1900^{4}\right)$, Eléments d'économie politique pure, ou théorie de la richesse sociale, Paris: Guillaumin, 1926; engl. trans. by W. Jaffé, London: Allen \& Unwin, 1954.

Wicksell, K. (1898), Geldzins und Güterpreise, Jena: G. Fischer; engl. trans. by R. Kahn, London: Macmillan, 1936. 